\title{
DRYING OF RESIDUAL GRAINS OF ANNATTO IN A HEAT ACCUMULATOR DRYER COMBINED WITH DRYING IN A SOLAR DRYER
}

\author{
DYEGO DA COSTA SANTOS* \\ ALEXANDRE JOSÉ DE MELO QUEIROZ** \\ ROSSANA MARIA FEITOSA DE FIGUEIRÊDO** \\ EMANUEL NETO ALVES DE OLIVEIRA***
}

\begin{abstract}
This paper is a study of the drying process of residual grains of annatto in a heat accumulator dryer during the night combined with a solar dryer during the day. Different mathematical models were adjusted regarding experimental data for the dryings and for determining the effective diffusivity for all the processes. The grains were divided into two groups; one with oil, reproducing the conditions of the grains after the oily extraction of bixin, and another group without oil. The drying of the annatto grains of during the night was performed with a heat accumulator dryer, which consisted of solar panel systems that heat water, which is transferred to a thermal tank where it is used as a heat source; during the day a solar dryer was used. Residual grains of annatto with an initial moisture at $\sim 18 \%$ w.b. were dehydrated until they reached $\sim 5 \%$ w.b. Combined drying using a heat accumulator dryer and a solar dryer proved to be efficient, with samples presenting lower amounts of moisture compared to the control samples. Midilli's equation was considered the best model to represent the kinetics of drying residual grains of annatto both with and without oil. Grain samples presented effective diffusivity in the order of $10^{-9} \mathrm{~m}^{2} \mathrm{~s}^{-1}$.
\end{abstract}

* Doutorando em Engenharia Agrícola, Universidade Federal de Campina Grande (UFCG), Campina Grande, PB (e-mail: diego.csantos@gmail.com).

** Doutor em Engenharia de Alimentos, Professor Associado, UFCG, Campina Grande, PB (e-mail: alex@ deag. ufcg.edu.br; rossana@deag.ufcg.edu.br).

*** Doutorando em Engenharia Agrícola, Professor, Instituto Federal de Educação, Ciência e Tecnologia do Rio Grande do Norte (IFRN), Pau dos Ferros, RN (e-mail: emanuel.oliveira16@gmail.com). 


\section{INTRODUCTION}

The annatto tree (Bixa orellana L.) produces oval, capsule-like fruits that contain seeds wrapped in a reddish layer, which are responsible for its typical color; the main pigment in the pericarp is bixin, which represents over $80 \%$ of total carotenoids. Annatto coloring is used in cosmetics, pharmaceutics and mainly, foods, due to the current tendency to replace synthetic colorings with natural ones (SANTOS et al., 2013).

After bixin is extracted, a large amount of residue is formed, which is constituted by grains of annatto impregnated with soya oil and vestiges of pigments. According to Silva et al. (2005), the agricultural exploration of annatto produces $97-98 \%$ of residual grains. Approximately 2,500 tonnes of annatto residues are obtained in Brazil yearly, particularly in the Northeast region. About $97 \%$ of that quantity is discarded (RÊGO et al., 2010). A small percentage of residual grains is used as food for animals (SILVA et al., 2005; RÊGO et al., 2010), however, the possibility of using such residues for human food products should also be considered because, similarly to other grains, annatto grains are rich in carbohydrates, protein and minerals (DIÓGENES, 2013).

Using residual grains of annatto in food production follows the global tendency for finding new purposes for agricultural residues. However, it requires knowledge of drying processes in order to guarantee stability until the subsequent procedures can be performed. Santos et al. (2013) report that stocking and commercializing agricultural products is necessary to reduce the moisture in the material and consequently its biological activity; drying is then the most common process to extend the life cycle because it guarantees stability during storage.

Drying demands great power, and obtaining such power usually leads to renewable sources. Amongst those renewable sources, solar power is the first alternative as it is abundant and is a direct source of heat. As Brazil's territory is mostly tropical, the country has a privileged position to produce and use solar power. In terms of the use of solar power for drying agricultural products, it is necessary to study the systems and processes that increase solar power's advantages (SANTOS et al., 2012).

The most commonly used method in tropical countries is sun drying; however, this technique is extremely dependent on the weather and can present cases of contamination or insect attack (DOYMAZ, 2009). Therefore, solar dryers provide a faster, more uniform and hygienic form of drying, which results in a better product for the food industry. Nonetheless Queiroz et al. (2011) have proposed a process that collects solar power through solar panels during the day and accumulates it in a water body in order to continue the drying process at night. Solar power stored in water during the day and used in drying during the night heats the air in the drying chamber at temperatures higher than $50^{\circ} \mathrm{C}$ (SANTOS et al., 2012).

The aim of this study was to dry annatto residual grains using a back-up heater during the night combined with solar drying during the day, and to adjust different mathematical models to experimental data from the dryings and determine the effective diffusion of the processes.

\section{MATERIAL AND METHODS}

Residual grains of annatto were donated by the Maratá, food producer whose headquarters are located in Sergipe State, Brazil; it is an industry that produces oily extraction of bixin. The grains were taken to the laboratory and stored in plastic recipients at a temperature of $-18{ }^{\circ} \mathrm{C}$ until the procedures started. The grains were impregnated with soya oil, which was a by-product of the extraction of bixin.

The residual grains were subjected to two treatments before drying: in the first the oil layer was kept (Treatment 1) and in the second it was removed by washing with water and neutral soap (Treatment 2). After this washing, the grains were distributed in thin layers on a laboratory stand until the superficial moisture was eliminated. The samples for Treatments 1 and 2 presented moisture 
percentages of $\sim 18 \%$ w.b. (21.95 \% d.b.).

The dryings were performed four times, each repetition using $15 \mathrm{~g}$ of samples, which were put in baskets made of wire mesh $10 \mathrm{~cm}$ long and wide, and $3 \mathrm{~cm}$ tall. Dryings were initiated at $17 \mathrm{~h}$ and continued until the samples reached moisture levels of $5 \%$ w.b. ( $5.26 \%$ d.b.); they were subjected to weight measurements at regular intervals of $15,30,60$ and $120 \mathrm{~min}$.

During the night, a back-up heater was used, which was developed to accumulate solar power in a body of water and transfer it to the drying chamber. The back-up heater absorbs solar power in solar panels and heats up water that is later used in night time drying as it passes through a heat exchanger. During the day, water is heated up and stored in a thermal isolated tank, which circulates with support from a pump fed by a photovoltaic panel. At night, warm water circulates from the thermal tank to the heat exchanger through thermosiphon. In this set up, when the heat is transferred to the drying chamber the water suffers a mass increase, moving to the lower part of the tank and enabling thermosiphon because the entrance and exit of the tank and the heat exchanger in downward spiral are positioned at convenient heights, which are different from each other. The thermosiphon principle also occurs in the circuit from the panels to the tank, but in this case warm water rises from the panels to the higher part of the thermal tank, drawing cold water from the bottom of the tank. On the other hand, the water pump, moved by photovoltaic power accelerated circulation, which enabled faster heating in the solar panels with shorter permanence time and consequently benefitting daylight events.

The schematic representation for the heat accumulator dryer is shown in Figure 1. During the day, water circulation controlled by valves was restricted to the panels-thermal tank circuit. At night, circulation in the panels-tank was interrupted and registers that allow circulation from the tank to the drying chamber. Half the samples of Treatments 1 and 2 were subjected to drying in the heat accumulator dryer and the other half were kept in a laboratory stand (control samples) and exposed to room temperature and relative humidity.

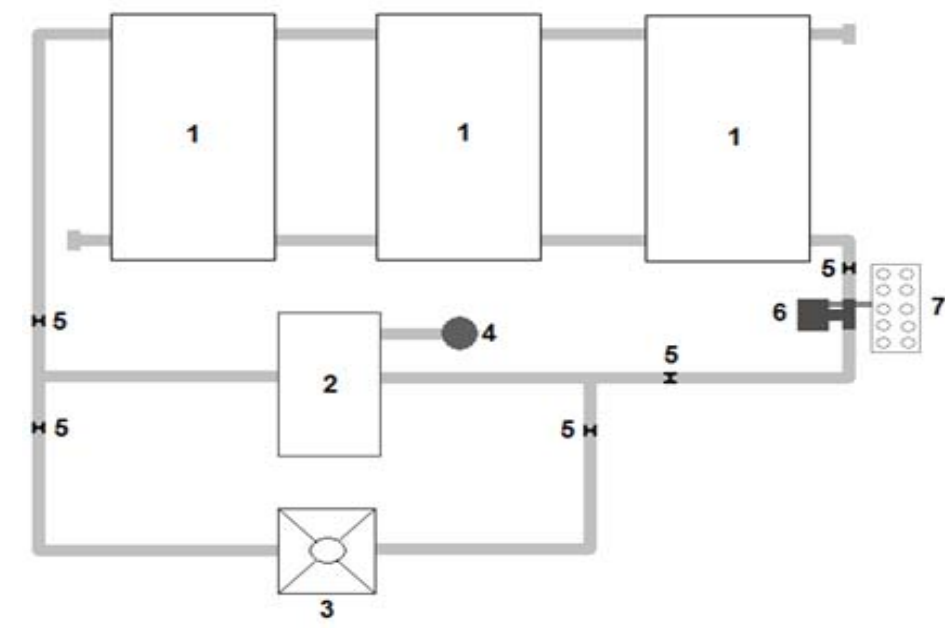

FIGURE 1 - SCHEMATICAL REPRESENTATION OF THE SOLAR ENERGY ACCUMULATIVE DRIER

1- solar collector, 2 - thermal reservoir, 3 - drying chamber, 4 - reservoir for water supply lost by evaporation, 5 - shut-off cock, 6 - water pump and 7 - photovoltaic panel.

Source: adapted from DIÓGENES (2010).

During daylight, starting at $8 \mathrm{~h}$, the samples in the heat accumulator dryer and the control samples were taken to the solar dryer (Figure 2) where drying continued. The solar dryer was built with galvanized sheet metal, internally covered with expanded polystyrene painted in black and covered with plain glass $4.0 \mathrm{~mm}$ thick. The dryer was square-shaped, $71 \mathrm{~cm}$ wide and $9 \mathrm{~cm}$ deep. 


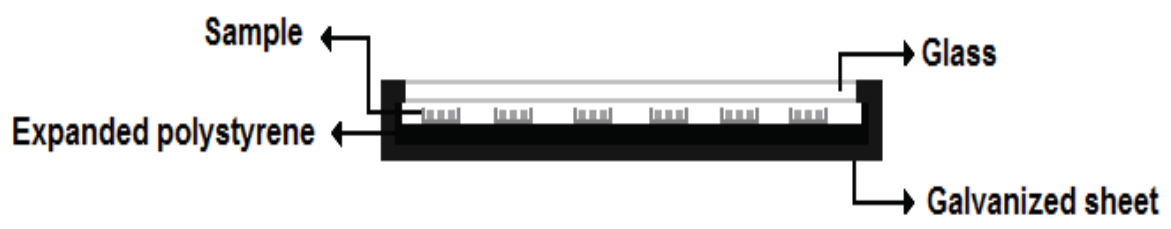

FIGURE 2 - SOLAR DRYER USED IN THE DRYINGS

Source: adapted from QUEIROZ et al. (2011).

When the samples reached the desired moisture level (5\% w.b.), which was verified through the difference between the initial and final mass of a given weight measurement, the exact moisture was determined in a oven at a temperature of $105 \pm 3{ }^{\circ} \mathrm{C}$ according to the methodology of the AOAC (2010).

The moisture ratio (DIÓGENES et al., 2013) was calculated from mass loss data in the samples during the dryings and moisture percentages determined at the end of each process, according to Equation 1:

$$
\operatorname{MR}=\frac{X-X_{e}}{X_{i}-X_{e}}
$$

Where: $M R=$ moisture ratio (dimensionless); $X=$ moisture content at any time $t$ (d.b.); $X_{i}=$ initial moisture content (d.b.) and $\mathrm{X}_{\mathrm{e}}=$ equilibrium moisture content (d.b.).

Mathematical models for diffusion approximation - Two Terms, Midilli, Page and Thompson (Table 1) - were adjusted to the experimental data obtained in the kinetics for drying of the residual annatto grains using Statistica 7.0 (STATSOFT, 2004) by non-linear regression using the QuasiNewton method (STATSOFT, 2004).

\section{TABLE 1 - MATHEMATICAL MODELS USED FOR FITTING OF DATA OF DRYING OF RESIDUAL ANNATTO GRAINS WITH AND WITHOUT OIL}

\begin{tabular}{|c|c|c|c|}
\hline Model name & Reference & Equation & \\
\hline Two Terms & DOYMAZ (2009) & $M R=a \cdot \exp (-k \cdot t)+b \cdot \exp (-q \cdot t)$ & (2) \\
\hline Midilli & $\begin{array}{c}\text { MIDILLI, KUCUK \& YAPAR } \\
\text { et al. (2002) }\end{array}$ & $M R=a \cdot \exp \left(-k \cdot t^{n}\right)+b \cdot t$ & (3) \\
\hline Page & KOUA et al. (2009) & $M R=\exp \left(-k \cdot t^{n}\right)$ & (4) \\
\hline Thompson & AKPINAR (2011) & $M R=\exp \left(\left(-a-\left(a^{2}+4 \cdot b \cdot t\right)^{0,5}\right) / 2 \cdot b\right)$ & (5) \\
\hline
\end{tabular}

Where: $t$ is drying time $(\min )$; $k$ is constant of drying $\left(\min ^{-1}\right)$ and $a, b, n, q$ are model coefficients.

The determination coefficient $\left(\mathrm{R}^{2}\right)$ and mean-square deviation (MSD) (SANTOS et al., 2014a) were used for evaluating the adjustments in the models to the data from the dryings (Equation 6): 


$$
\operatorname{MSD}=\left[\frac{1}{n} \sum_{i=1}^{n}\left(M R_{p r e d, i}-M R_{\text {exp,i }}\right)^{2}\right]^{1 / 2}
$$

Where: $\mathrm{MSD}=$ mean-square deviation; $\mathrm{MR}_{\mathrm{pred}, \mathrm{i}}=$ predicted moisture ratio (dimensionless); $\mathrm{MR}_{\text {exp } \mathrm{i}}=$ experimental moisture ratio (dimensionless) and $\mathrm{n}=$ number of observations.

Drying ratios (SANTOS et al., 2014b) were calculated from moisture in the samples and drying times (Equation 7):

$$
\mathrm{DR}=\frac{\mathrm{X}_{\mathrm{t}+\mathrm{dt}}-\mathrm{X}_{\mathrm{t}}}{\mathrm{dt}}
$$

Where: $\mathrm{DR}=$ drying ratio $\left(\mathrm{kg} \mathrm{kg}^{-1} \cdot \mathrm{min}^{-1}\right) ; \mathrm{X}_{\mathrm{t}+\mathrm{dt}}=$ moisture percentage at $\mathrm{t}+\mathrm{dt}(\mathrm{kg}$ water $/ \mathrm{kg}$ dry basis $) ; \mathrm{X}_{\mathrm{t}}=$ moisture at a time $\mathrm{t}$ (kg water/kg dry basis); $\mathrm{t}=$ drying time $(\mathrm{min})$.

To determine the effective diffusivity (CRANK, 1975), based on Diffusion Theory (Fick's laws of diffusion), data from the dryings were adjusted to the liquid diffusion model for spherical shape, with approximation by three terms (Equation 8), considering the uniformity of the equivalent sphere radius for the grains during the drying:

$$
M R=\frac{X-X e}{X i-X e}=\frac{6}{\pi^{2}} \sum_{n=1}^{\infty} \frac{1}{n^{2}} \exp \left[-\frac{n^{2} \pi^{2} D_{e f} t}{R_{e q}^{2}}\right]
$$

Where: $M R=$ moisture ratio, dimensionless; $D_{\text {ef }}=$ effective moisture diffusivity, $\mathrm{m}^{2} \mathrm{~s}^{-1} ; \mathrm{n}=$ number of terms; $\mathrm{R}_{\mathrm{eq}}=$ radius of the equivalent sphere, $\mathrm{m}$; and $\mathrm{t}=$ time, $\mathrm{s}$.

To calculate the radius of the sphere equivalent to the samples in Treatments 1 and 2 , the volume of 100 grains (50 grains with oil and 50 grains without it) was first determined by the water displacement method (MOHSENIN, 1986), and equivalent radius by the volume of an equivalent sphere (Equation 9):

$$
\mathrm{V}_{\mathrm{g}}=\frac{4}{3} \pi \mathrm{r}^{3}
$$

Where: $V_{g}=$ volume of the grain $\left(m^{3}\right)$ and $r=$ the equivalent sphere radius $(m)$.

In the statistical analysis of the diffusion values, a completely randomized design was used in a $4 \times 2 \times 4$ factorial scheme; 4 being samples, 2 being the types of combined drying, and four repetitions. Data were subjected to variance analysis, and comparison between means was achieved by Tukey's test $(p<0.05)$ using Assistat (SILVA and AZEVEDO, 2002).

\section{RESULTS AND DISCUSSION}

The temperature variations during the drying of the residual grains of annatto in the heat accumulator dryer at night and solar dryer during the day are shown in Figure 3. At night, the temperature inside the heat accumulator dryer (AC dryer) was higher than room temperature for the laboratory stand. The mean temperatures inside the AC dryer were $49.94{ }^{\circ} \mathrm{C}$ (Treatment 1 ) and $47.90{ }^{\circ} \mathrm{C}$ (Treatment 2) when the temperatures for the stand reached $64^{\circ} \mathrm{C}$ (Treatment 1 ) and 
$24.14{ }^{\circ} \mathrm{C}$ (Treatment 2). In spite of the reduction of temperatures in the AC dryer as the drying continued, which was due to heat loss in the warm water, it was verified that the temperature stayed above $45^{\circ} \mathrm{C}$. During the day, the temperature inside the solar dryer surpassed that registered for the AC dryer. The mean temperatures inside the solar dryer reached 88.45 and $71.47^{\circ} \mathrm{C}$ for the samples with and without oils, respectively.
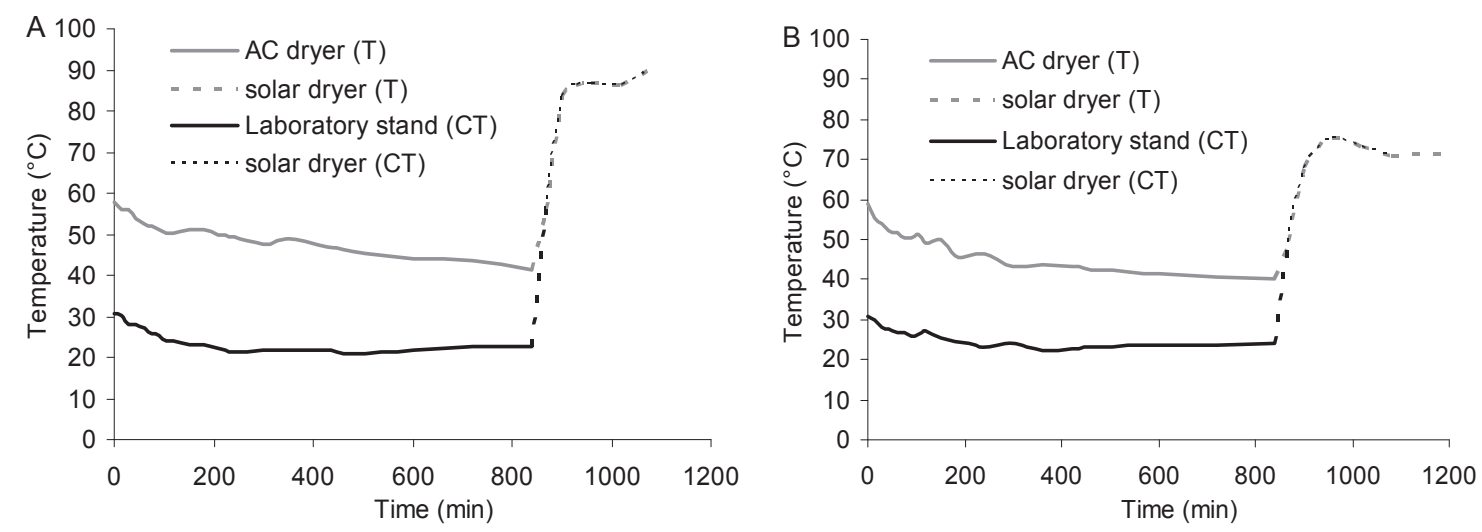

\section{FIGURE 3 - TEMPERATURE INSIDE HEAT ACCUMULATOR DRYER (AC DRYER), SOLAR DRYER AND EXTERNAL ENVIRONMENT DURING DRYINGS OF SAMPLES OF TREATMENTS 1(A) AND 2(B) FOR NIGHT AND DAY}

Where: T (treatment); CT (control sample).

The variation in relative humidity for the dryings of the residual grains of annatto in the AC dryer at night is shown in Figure 4. The relative humidity inside the AC dryer reached $55.06 \%$ (Treatment 1) and $58.56 \%$ (Treatment 2), while mean values for the same parameter for the laboratory stand reached $79.63 \%$ and $80.06 \%$ for samples of residual grains of annatto with and without oil, respectively.
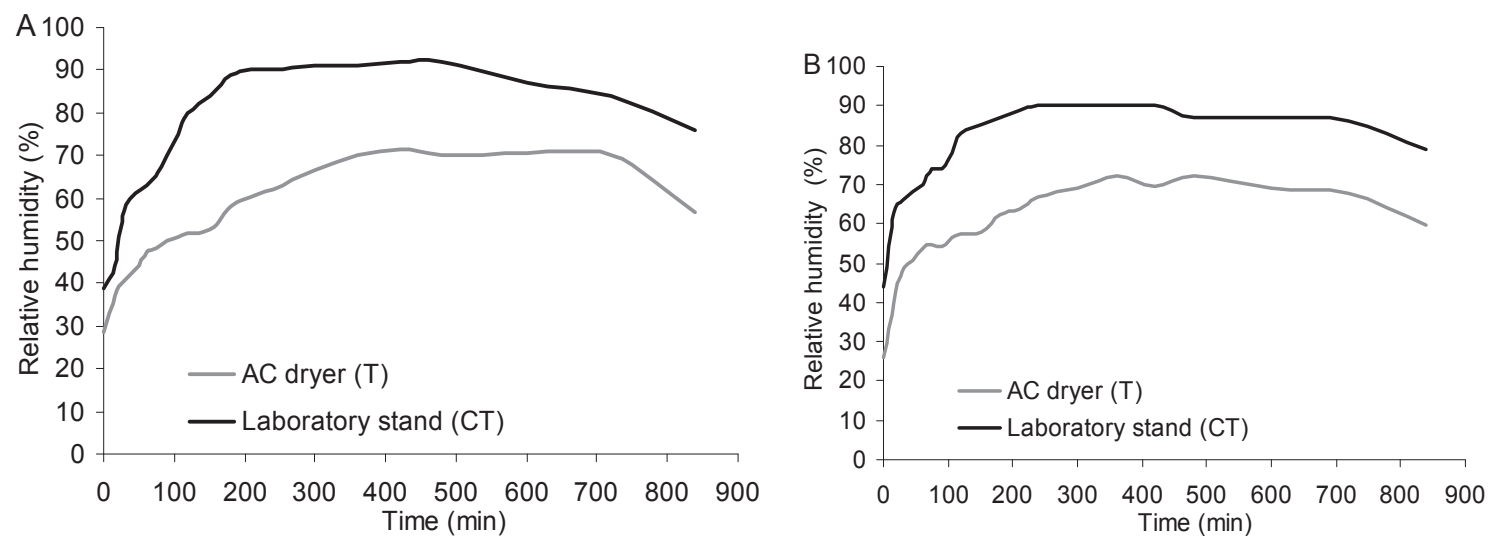

\section{FIGURE 4 - RELATIVE HUMIDITY INSIDE THE HEAT ACCUMULATOR DRYER (AC DRYER) AND EXTERNAL ENVIRONMENT DURING DRYINGS OF SAMPLES FROM TREATMENT 1(A) AND 2(B) AT NIGHT}

Where: T (treatment); CT (control sample).

Experimental points of curve for dryings of samples with oil (Treatment 1) and without oil (Treatment 2) dehydrated in AC dryer at night and in solar dryer during the day. Regarding the night time, the treatments dried in the AC dryer lost moisture at a higher ratio than the control samples that 
were on the laboratory stand. By the end of the first drying $(840 \mathrm{~min})$ the mean values for moisture ratio (MR) were approximately 0.13 and 0.15 for the samples from Treatments 1 and 2, respectively, while the control samples presented a MR of 0.31 (Treatment 1) and 0.27 (Treatment 2). Such results demonstrate the efficiency of the AC dryer during the night, which is confirmed by Queiroz et al. (2011), who studied the solar drying of jackfruit and affirmed that storing solar power in a body of water is feasible from a technical point of view for night dryings. Santos et al. (2012) investigated drying processes for flour from residual grains of annatto using solar power and verified that the AC dryer enabled the drying of samples at night.

During the day (Figure 5), samples of Treatments 1 and 2 and their respective control samples were subjected to solar drying to ensure the continuity of the process. It was verified that Treatments 1 and 2 continued to lose moisture at a lower rate than the control samples; however, they lost a lower percentage of moisture at night. Such observations are related to the higher percentage of moisture available in the control samples regarding the treatments that were first dehydrated in the AC dryer, and the higher temperatures in the solar dryer. The dryings were interrupted when the samples reached the desired moisture level ( $\sim \%$ w.b.) at 1080 and 1200 minutes for Treatments 1 and 2, respectively.
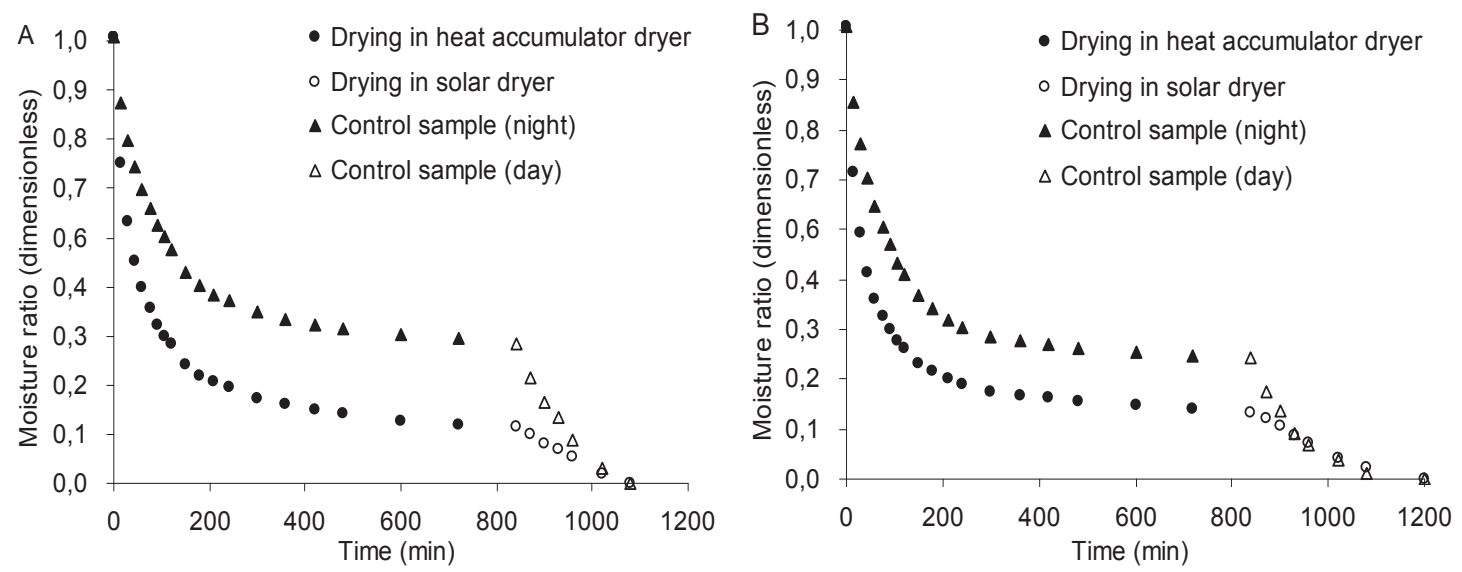

\section{FIGURE 5 - CURVES FOR DRYINGS OF SAMPLES OF TREATMENTS 1(A) AND 2(B) DEHYDRATED IN HEAT ACCUMULATOR DRYER AND SOLAR DRYER}

The longer drying period for the samples of Treatment 2 was due to the weather during the experiment; inside the AC and solar dryer the temperatures were lower than Treatment 1 , which consequently caused higher relative moisture.

The drying rates for Treatments $1(\mathrm{~A})$ and $2(\mathrm{~B})$ dehydrated in the $\mathrm{AC}$ dryer during the night and the solar dryer during the day are shown in Figure 6 . The highest drying rates were found in samples that started dehydration in the AC dryer compared to the control samples. Such results are related to the thermodynamic parameters of the laboratory stand, where the mean temperatures registered were lower than $25{ }^{\circ} \mathrm{C}$ and relative humidity was almost $80 \%$, which is in agreement with Prasad (2009), who affirms that the drying rate also depends on external parameters, such as room temperature and relative humidity. The drying rated decreased as dehydration continued as a result of moisture reduction until 840 minutes, the time at which the night dryings were stopped. During the day, correspondent to solar drying, a slight elevation in drying rates was noticed, which was due to temperatures over $70{ }^{\circ} \mathrm{C}$ inside the dryer. This was more evident in the control samples with late decrease of said rates, which reinforces the findings of different studies on the solar drying of agricultural products such as chili pepper (HOSSAIN and BALA, 2007), banana (KOUA et al., 2009), cocoa (HII, LAW and CLOKE, 2009), mint leaves (SALEH and BADRAN, 2009), red pepper (BANOUT et al., 2011), seedless grape (ÇAKMAK and YILDIZ, 2011) and orange peel (SLAMA and COMBARNOUS, 2011). 

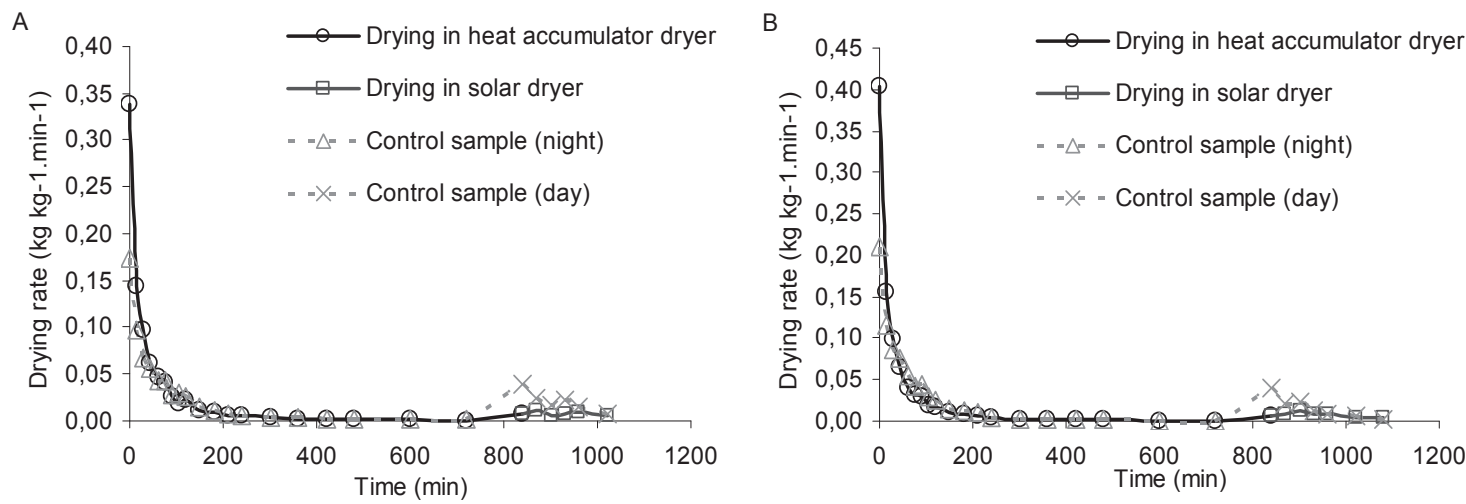

\section{FIGURE 6 - DRYING RATES FOR SAMPLES OF TREATMENTS 1(A) AND 2(B) DEHYDRATED IN HEAT ACCUMULATOR DRYER AND SOLAR DRYER}

At the beginning of dehydration, Treatment 2 presented the highest drying rate, corresponding to $\sim 0.40 \mathrm{~kg} \mathrm{~kg}^{-1}$. $\mathrm{min}^{-1}$, while samples for Treatment 1 showed a drying rate of $\sim 0.34 \mathrm{~kg} \mathrm{~kg}^{-1}$. $\mathrm{min}^{-1}$ (Figure 6), which might have been due to higher temperatures inside the AC dryer at the beginning of dryings for Treatment $2\left(58.80^{\circ} \mathrm{C}\right)$ compared to samples from Treatment $1\left(57.60^{\circ} \mathrm{C}\right)$. Constant drying rates were not observed. Doymaz (2011) states that when drying speed decreases, the surface of the material is no longer saturated with moisture, therefore drying speed is controlled by the diffusion of moisture from the interior to the surface of the samples. As moisture rates were reduced with the ongoing dryings of samples from Treatments 1 and 2 , it is natural that drying rates would reduce as well, confirming reports by Resende et al. (2009), who noted that by the end of the dryings, moisture was deeply linked. Thus the need for extra power to its evaporation, in a way that dehydration of Treatments 1 and 2 occur at progressively lower speeds, consequence of lower drying rates.

The initial and final moisture rates for Treatments 1 and 2 that were dehydrated in the AC dryer during the night combined with the solar dryer during the day are shown in Table 2. In the first drying, which corresponded to nigh dehydration, Treatments 1 and 2 in the AC dryer lost an extra $67 \%$ moisture, while the control samples lost less than $60 \%$. The moisture rates at the end of the night dryings were higher than $9 \%$ d.b. for the control samples, while samples in the AC dryer presented moisture rates lower than $7.5 \%$ d.b. Similar results were reported by Santos et al. (2012), who studied the drying of flour of residual grains of annatto in an AC dryer. Those authors verified that samples dried in an $\mathrm{AC}$ dryer presented lower moisture rates at the end of the process compared to the control samples.

TABLE 2 - INITIAL AND FINAL MOISTURE RATES FOR SAMPLES FROM TREATMENTS 1 AND 2 DEHYDRATED IN AC DRYER DURING THE NIGHT AND SOLAR DRYER DURING THE DAY

\begin{tabular}{|c|c|c|c|c|c|c|}
\hline \multirow[b]{2}{*}{ Sample } & \multicolumn{3}{|c|}{ AC dryer/Solar dryer } & \multicolumn{3}{|c|}{ Laboratory stand / Solar dryer * } \\
\hline & $\begin{array}{l}\text { Initial } \\
\text { (\% w.b.) }\end{array}$ & $\begin{array}{c}\text { Final } \\
\text { (\% w.b.) }\end{array}$ & $\begin{array}{l}M L \\
(\%)\end{array}$ & $\begin{array}{l}\text { Initial } \\
\text { (\% w.b.) }\end{array}$ & $\begin{array}{l}\text { Final } \\
\text { (\% w.b.) }\end{array}$ & $\begin{array}{l}\text { ML } \\
(\%)\end{array}$ \\
\hline Treatment 1 (night) & $\#_{21.11}$ & $\# 6.80$ & $\# 67.79$ & ${ }^{\circ} 21.11$ & •9.85 & ${ }^{\circ} 53.34$ \\
\hline Treatment 1 (day) & ${ }^{\square} 6.80$ & ${ }^{a} 5.02$ & ${ }^{\mathrm{2}} 26.18$ & 9.85 & "5.36 & 45.58 \\
\hline Treatment 2 (night) & $\# 22.13$ & $\# 7.27$ & $\# 67.15$ & ${ }^{\circ} 22.13$ & •9.38 & จ57.61 \\
\hline Treatment 2 (day) & ${ }^{\square} 7.27$ & ${ }^{\square} 5.05$ & ${ }^{\square} 30.54$ & ${ }^{\circ} 9.38$ & ${ }^{a} 5.34$ & ${ }^{\square} 43.07$ \\
\hline
\end{tabular}

${ }^{*}$ Control sample; ${ }^{\sharp} \mathrm{AC}$ dryer process; ${ }^{\circ}$ Drying in laboratory stand; ${ }^{\mathrm{a}}$ Drying in solar dryer; $\mathrm{ML}=$ Moisture loss. 
During the second drying, which corresponded to the daytime dehydrations, it was verified that the control samples that were dried in the solar dryer lost over $43 \%$ of moisture, while the samples from Treatments 1 and 2 lost less than $31 \%$ (Table 2), thus demonstrating higher drying rates for daytime dehydrations for the control samples (Figure 6). By the end of the daytime dehydrations, the samples from Treatments 1 and 2 presented lower moisture rates compared to the control samples, in spite of the fact that they had lost more moisture in the solar dryer. These results are related to the AC dryer during the night, which confirms its efficiency.

Table 3 shows the parameters of adjustment for the Two Terms, Midilli, Page and Thompson models for the experimental data from the kinetics for the dryings of the samples from Treatments 1 and 2, their respective determination coefficient (R2), and the mean-square deviation (MSD). The control samples (identified as "CT night" or "CT day") and samples from Treatments 1 and 2 (identified as "night" or "day") were adjusted by excerpts, with adjustments to the mathematical models regarding the data from the drying kinetics relating to the night-time dryings in the AC dryer and afterwards, data from the daytime dehydrations in the solar dryer. Justification for the adjustment being done in parts is found in the fact that dryings processed at night and during the day behave differently, with abrupt transitions, high relative moisture and relatively lower temperatures at night, and elevated temperatures and lower relative moisture during the day, in solar drying.

Midilli's equation was selected as the best model to represent the kinetics for the dryings of the samples from Treatments 1 and 2 dehydrated in AC dryer during the night combined with the solar dryer during the day; these presented values of R2 higher than 0.99 and some lower values of MSD (Table 3). It was also verified that all the mathematical models that were evaluated presented R2 higher than 0.92 and lower MSD values, which could be used to predict the kinetics of dryings for samples from Treatments 1 and 2.

Researchers have also reported good adjustments to these mathematical models when performing solar drying of agricultural products. Mohamed et al. (2008) dried Gelidium sesquipedale in a solar dryer and verified that the Two Terms, Midilli and Page mathematical models showed a good adjustment to experimental data from dryings. Akbulut and Durmuş (2009) studied mathematical models of dryings of blackberry in a solar dryer and reported good adjustment for Midilli's model. Akpinar (2011) dehydrated parsley in a solar dryer and reported good adjustment of Thompson model to experimental data, with R2 values higher than 0.99.

Data for moisture ratio (MR), experimental and estimated, built with Midilli's model for the drying of samples from Treatments 1 and 2, dehydrated in an AC dryer during the night and a solar dryer during the day are shown in Figure 7. A good adjustment of the model to the experimental data of dryings of residual grains of annatto was noticed. There was no evidence of a great dispersion of experimental points regarding the line that passes the origin and which theoretically represents equality between experimental and estimated values, confirming the adequacy of the adjustments.

The values for the mean effective diffusivity determined for the dryings of samples from Treatments 1 and 2 dehydrated in an AC dryer, a solar dryer, and a laboratory stand (control samples) are presented in Table 4. A significance of $1 \%$ probability by $F$ test was observed for the different types of samples (Treatments 1 and 2 during the day and night) and for the different drying processes (heat accumulator dryer/solar dryer; external environment/solar dryer), as well as for interaction type of sample/type of drying. All the values for diffusivity presented statistical difference between each other by Tukey's test $(p<0.05)$.

Treatments 1 and 2, and their respective controls, presented effective diffusivity in the order of $10^{-9} \mathrm{~m}^{2} \mathrm{~s}^{-1}$ (Table 4) fitting the variation from $10^{-9}$ to $10-11 \mathrm{~m}^{2} \mathrm{~s}^{-1}$ reported by Madamba, Driscoll and Buckle (1996) for drying of agricultural products. Effective diffusivity values in the order of $10^{-9} \mathrm{~m}^{2} \mathrm{~s}^{-1}$ were also reported in soya grains (NIAMNUY et al., 2012), fermented grape marc (FERREIRA et al., 2012), bell pepper (GARAVAND, RAFIEE and KEYHANI, 2011), sweet cherry (DOYMAZ and ISMAIL, 2011) and blackberry (AKBULUT and DURMUŞ, 2009). 
TABLE 3 - PARAMETERS FOR MATHEMATICAL MODELS WITH THEIR RESPECTIVE

DETERMINATION COEFFICIENTS $\left(R^{2}\right)$ AND MEAN-SQUARE DEVIATION (MSD) FOR KINETICS OF DRYINGS FOR SAMPLES FROM TREATMENTS 1 AND 2 IN AC DRYER DURING THE NIGHT AND SOLAR DRYER DURING THE DAY, WITH THEIR RESPECTIVE CONTROL SAMPLES (CT)

\begin{tabular}{|c|c|c|c|c|c|c|c|c|}
\hline \multirow{2}{*}{ Model } & \multirow{2}{*}{ Sample } & \multicolumn{7}{|c|}{ Parameter } \\
\hline & & a & b & k & $\mathbf{n}$ & q & $\mathbf{R}^{2}$ & MSD \\
\hline \multirow{8}{*}{ 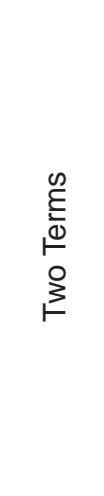 } & Treatment 1 (night) & 0.5555 & 0.4374 & 0.0419 & - & 0.0061 & 0.9988 & 0.0047 \\
\hline & Treatment 1 (day) & 0.5379 & 0.5379 & 0.0078 & - & 0.0078 & 0.9325 & 0.0342 \\
\hline & Treatment 1 (CT night) & 0.4293 & 0.5572 & 0.0249 & - & 0.0057 & 0.9988 & 0.0035 \\
\hline & Treatment 1 (CT day) & 0.5271 & 0.4962 & 0.0102 & - & 0.0102 & 0.9793 & 0.0262 \\
\hline & Treatment 2 (night) & 0.3820 & 0.6119 & 0.0068 & - & 0.0480 & 0.9985 & 0.0081 \\
\hline & Treatment 2 (day) & 0.5371 & 0.5430 & 0.0064 & - & 0.0064 & 0.9655 & 0.0312 \\
\hline & Treatment 2 (CT night) & 0.5338 & 0.4519 & 0.0216 & - & 0.0065 & 0.9990 & 0.0039 \\
\hline & Treatment 2 (CT day) & 0.5019 & 0.5019 & 0.0106 & - & 0.0106 & 0.9971 & 0.0129 \\
\hline \multirow{8}{*}{ 竞 } & Treatment 1 (night) & 1.0047 & 0.00001 & 0.0774 & 0.6281 & - & 0.9990 & 0.0024 \\
\hline & Treatment 1 (day) & 1.0023 & -0.00155 & 0.0012 & 1.2281 & - & 0.9992 & 0.0019 \\
\hline & Treatment 1 (CT night) & 1.0019 & 0.00001 & 0.0312 & 0.7602 & - & 0.9995 & 0.0012 \\
\hline & Treatment 1 (CT day) & 0.9972 & -0.00087 & 0.0101 & 0.9261 & - & 0.9995 & 0.0000 \\
\hline & Treatment 2 (night) & 1.0039 & 0.00001 & 0.0967 & 0.6120 & - & 0.9989 & 0.0032 \\
\hline & Treatment 2 (day) & 1.0105 & -0.00021 & 0.0010 & 1.3429 & - & 0.9990 & 0.0036 \\
\hline & Treatment 2 (CT night) & 1.0008 & 0.00001 & 0.0280 & 0.8138 & - & 0.9995 & 0.0020 \\
\hline & Treatment 2 (CT day) & 0.9967 & -0.00009 & 0.0099 & 1.0053 & - & 0.9985 & 0.0004 \\
\hline \multirow{8}{*}{ 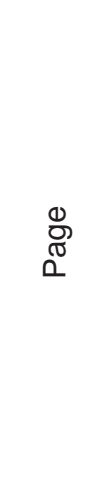 } & Treatment 1 (night) & - & - & 0.0779 & 0.6249 & - & 0.9989 & 0.0068 \\
\hline & Treatment 1 (day) & - & - & 0.0005 & 1.5618 & - & 0.9837 & 0.0292 \\
\hline & Treatment 1 (CT night) & - & - & 0.0318 & 0.7548 & - & 0.9994 & 0.0055 \\
\hline & Treatment 1 (CT day) & - & - & 0.0035 & 1.2246 & - & 0.9886 & 0.0228 \\
\hline & Treatment 2 (night) & - & - & 0.0997 & 0.6028 & - & 0.9986 & 0.0113 \\
\hline & Treatment 2 (day) & - & - & 0.0006 & 1.4572 & - & 0.9974 & 0.0124 \\
\hline & Treatment 2 (CT night) & - & - & 0.0291 & 0.8038 & - & 0.9993 & 0.0102 \\
\hline & Treatment 2 (CT day) & - & - & 0.0084 & 1.0510 & - & 0.9976 & 0.0104 \\
\hline \multirow{8}{*}{ 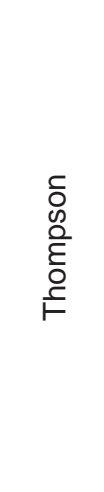 } & Treatment 1 (night) & -2.44088 & 0.3123 & - & - & - & 0.9997 & 0.0009 \\
\hline & Treatment 1 (day) & -4104.31 & 5.4320 & - & - & - & 0.9200 & 0.0127 \\
\hline & Treatment 1 (CT night) & -6.66249 & 0.3231 & - & - & - & 0.9991 & 0.0073 \\
\hline & Treatment 1 (CT day) & -4451.50 & 6.6389 & - & - & - & 0.9783 & 0.0152 \\
\hline & Treatment 2 (night) & -1.96508 & 0.3324 & - & - & - & 0.9996 & 0.0054 \\
\hline & Treatment 2 (day) & -4521.40 & 5.1356 & - & - & - & 0.9530 & 0.0163 \\
\hline & Treatment 2 (CT night) & -8.80555 & 0.3798 & - & - & - & 0.9993 & 0.0022 \\
\hline & Treatment 2 (CT day) & -3805.01 & 6.3495 & - & - & - & 0.9971 & 0.0113 \\
\hline
\end{tabular}




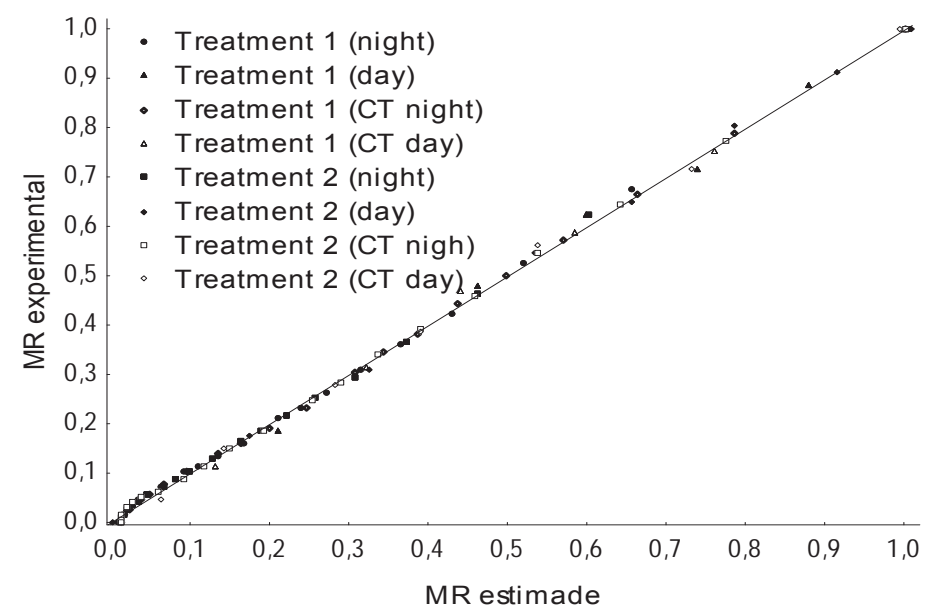

FIGURE 7 - RELATIONSHIP BETWEEN EXPERIMENTAL AND ESTIMATED VALUES FOR THE MOISTURE RATIO BY MIDILLI'S MODEL FOR THE KINETICS FOR DRYINGS OF SAMPLES FROM TREATMENTS 1 AND 2 IN AC DRYER DURING THE NIGHT AND SOLAR DRYER DURING THE DAY

TABLE 4 - MEAN VALUES OF EFFECTIVE DIFFUSIVITY $\left(\mathrm{m}^{2} \mathrm{~s}^{-1}\right)$ OBTAINED THROUGH THE DRYING OF RESIDUAL GRAINS IN HEAT ACCUMULATOR DRYER AND SOLAR DRYER

\begin{tabular}{|c|c|c|}
\hline Sample & AC dryer/Solar dryer & Laboratory stand / Solar dryer * \\
\hline Treatment 1 (night) & ${ }^{\#} 3.08 \times 10^{-9} \mathrm{bA}$ & ${ }^{\ni} 1.98 \times 10^{-9} \mathrm{cB}$ \\
\hline Treatment 1 (day) & ${ }^{\square} 1.27 \times 10^{-9} \mathrm{aA}$ & ${ }^{\square} 1.96 \times 10^{-9} \mathrm{~dB}$ \\
\hline Treatment 2 (night) & $\# 3.88 \times 10^{-9} \mathrm{dA}$ & ${ }^{\ominus} 2.37 \times 10^{-9} \mathrm{bB}$ \\
\hline Treatment 2 (day) & ${ }^{\square} 1.02 \times 10^{-9} \mathrm{cA}$ & $2.13 \times 10^{-9} \mathrm{aB}$ \\
\hline
\end{tabular}

*Control sample; \#Drying in AC dryer; 'Drying in laboratory stand; "Drying in solar dryer; Means followed by the same later, lower case in columns and capitals in lines do not differ statistically to $5 \%$ probability by Tukey's test. Least significant difference for columns $=1.59 \times 10^{-9}$; least significant difference for lines $=1,19 \times 10^{-9}$.

The highest values for diffusivity were found in for samples in the AC dryer during the night, which might be related to the elimination of superficial moisture of samples during the night due to lesser resistance of moisture towards diffusion, accordingly to the drying rate values presented in Figure 6. During the day, as the moisture was located in the more interior regions of the grains, diffusion was slower. Analyzing the control samples during the night, it was noticed that the diffusivity was lower than for the samples from Treatments 1 and 2 in the AC dryer, however, in the case of the solar dryer during the day, the diffusivity of the control samples was higher than for the samples from Treatments 1 and 2, which might be related to a greater amount of moisture in the samples, as they lost less moisture than before (Table 2).

\section{CONCLUSION}

Using a heat accumulator dryer during the night, combined with drying in a solar dryer during the day, proved efficient for drying residual grains of annatto with and without oil, reaching 
lower rates of moisture compared to the control samples.

Treatments dehydrated in the heat accumulator dryer at night presented higher values of effective diffusivity compared to the solar dryings.

All the mathematical models that were evaluated satisfactorily represented the drying of residual grains of annatto with and without oil. Midilli's model presented the best parameters of adjustment.

\section{RESUMO}

\section{SECAGEM DE GRÃOS RESIDUAIS DE URUCUM EM SECADOR ACUMULADOR DE CALOR COMBINADA COM SECAGEM EM SECADOR SOLAR}

Este trabalho teve por objetivo efetuar a secagem de grãos residuais de urucum em secador acumulador de calor no período noturno, combinada com secagem em secador solar no período diurno, bem como ajustar os dados experimentais das secagens a diferentes modelos matemáticos e determinar a difusividade efetiva dos processos. Os grãos foram divididos em dois lotes, um com óleo reproduzindo as condições dos grãos após a extração oleosa da bixina, e o outro sem óleo. A secagem dos grãos de urucum no período diurno ocorreu em secador solar e durante a noite em secador acumulador de calor que consiste em sistema de painéis solares que aquecem água, a qual é transferida para reservatório térmico e utilizada como fonte de calor. Os grãos residuais de urucum com teor de umidade inicial de $\sim 18 \%$ b.u. foram desidratados até o teor de umidade de $\sim 5 \%$ b.u. As secagens combinadas em secador acumulador de calor e em secador solar mostraram-se eficientes, obtendo-se amostras com menores teores de umidade em comparação às amostras controle. A equação de Midilli foi considerada como o melhor modelo para representar as cinéticas de secagem dos grãos residuais de urucum com e sem óleo. As amostras de grãos apresentaram difusividade efetiva na ordem de $10^{-9} \mathrm{~m}^{2} \mathrm{~s}^{-1}$.

PALAVRAS-CHAVE: Bixa orellana L.; RESÍDUOS AGRÍCOLAS; SECAGEM SOLAR.

\section{REFERENCES}

1 AKBULUT, A.; DURMUŞ, A. Thin layer solar drying and mathematical modeling of mulberry. International Journal of Energy Research, London, v.33, n.7, p.687-695, 2009.

2 AKPINAR, E. K. Drying of parsley leaves in a solar dryer and under open sun: modeling, energy and exergy aspects. Journal of Food Process Engineering, London, v.34, n.1, p.27-48, 2011.

3 Association of Official Analytical Chemists (AOAC). Official methods of analysis of AOAC International. $18^{\text {th }}$ ed. $3^{\text {th }}$ rev. Washington, 2010. 1094 p.

4 BANOUT, J.; EHL, P.; HAVLIK, J.; LOJKA, B.; POLESNY, Z.; VERNER, V. Design and performance evaluation of a double-pass solar drier for drying of red chilli (Capsicum annum L.). Solar Energy, Freiburg, v.85, n.3, p.506-515, 2011.

5 ÇAKMAK, G.; YILDIZ, C. The drying kinetics of seeded grape in solar dryer with PCM-based solar integrated collector. Food and Bioproducts Processing, Rugby, v.89, n.2, p.103-108, 2011.

6 CRANK, J. The mathematics of diffusion. $2^{\text {th }}$ ed. Oxford: Clarendon Press, 1975. 421p.

7 DIÓGENES, A. M. G. Secagem solar e convencional de grãos de abóbora. 2010. 155 f. Dissertação (Mestrado em Engenharia Agrícola) - Universidade Federal de Campina Grande, Campina Grande, 2010.

8 DIÓGENES, A. M. G.; QUEIROZ, A. J. M.; FIGUEIRÊDO, R. M. F.; SANTOS, D. C. Cinética de secagem de grãos de abóbora. Revista Caatinga, Mossoró, v.26, n.1, p.71-80, 2013.

9 DOYMAZ, I. Drying of green bean and okra under solar energy. Chemical Industry \& Chemical Engineering Quarterly, Beograd, v.17, n.2, p.199-205, 2011.

10 DOYMAZ, I. Mathematical modelling of thin-layer drying of kiwifruit slices. Journal of Food Processing and Preservation, Trumbull, v.33, Suplemento 1, p.145-160, 2009.

11 DOYMAZ, I.; ISMAIL, O. Drying characteristics of sweet cherry. Food and Bioproducts Processing, Rugby, v.89, n.1, p.31-38, 2011. 
12 FERREIRA, L. F. D.; PIROZI, M. R.; RAMOS, A. M.; PEREIRA, J. A. M. Modelagem matemática da secagem em camada delgada de bagaço de uva fermentado. Pesquisa Agropecuária Brasileira, Brasília, v.47, n.6, p.855-862, 2012.

13 GARAVAND, A. T.; RAFIEE, S.; KEYHANI, A. Study on effective moisture diffusivity, activation energy and mathematical modeling of thin layer drying kinetics of bell pepper. Australian Journal of Crop Science, Sydney, v.5, n.2, p.128-131, 2011.

14 HII, C. L.; LAW, C. L.; CLOKE, M. Modeling using a new thin layer drying model and product quality of cocoa. Journal of Food Engineering, Oxford, v.90, n.2, p.191-198, 2009.

15 HOSSAIN, M. A.; BALA, B. K. Drying of hot chilli using solar tunnel drier. Solar Energy, Freiburg, v.81, n.1, p.85-92, 2007.

16 KOUA, K. B.; FASSINOU, W. F.; GBAHA, P.; TOURE, S. Mathematical modelling of the thin layer solar drying of banana, mango and cassava. Energy, Oxford, v.34, n.10, p.1594-1602, 2009.

17 MADAMBA, P. S.; DRISCOLL, R. H.; BUCKLE, K. A. The thin-layer drying characteristics of garlic slices. Journal of Food Engineering, Oxford, v.29, n.1, p.75-97, 1996.

18 MIDILLI, A.; KUCUK, H.; YAPAR, Z. A new model for single layer drying. Drying Technology, New York, v.20, n.7, p.1503-1513, 2002

19 MOHAMED, L. A.; KANE, C. S. E.; KOUHILA, M.; JAMALI, A.; MAHROUZ, M.; KECHAOU, N. Thin layer modelling of Gelidium sesquipedale solar drying process. Energy Conversion and Management, London, v.49, n.5, p.940-946, 2008.

20 MOHSENIN, N. N. Physical properties of plant and animal materials. New York: Gordon and Breach Publishers, 1986. $841 \mathrm{p}$.

21 NIAMNUY, C.; NACHAISIN, M.; POOMSA-AD, N.; DEVAHASTIN, S. Kinetic modelling of drying and conversion/ degradation of isoflavones during infrared drying of soybean. Food Chemistry, Oxford, v.133, n.3, p.946-952, 2012.

22 PRASAD, J. A. Convective heat transfer in herb and spices during open sundrying. International Journal of Food Science and Technology, Oxford, v.44, n.4, p.657-665, 2009.

23 QUEIROZ, A. J. M.; DANTAS, H. J.; FIGUEIREDO, R. M. F.; MELO, K. S. Solar drying of jack fruit almonds. Engenharia Agrícola, Jaboticabal, v.31, n.6, p.1150-1161, 2011.

24 RÊGO, A. C.; CÂNDIDO, M. J. D.; PEREIRA, E. S.; FEITOSA, J. V.; RÊGO, M. M. T. Degradação de silagens de capimelefante contendo subproduto do urucum. Revista Ciência Agronômica, Fortaleza, v.41, n.3, p.482-489, 2010.

25 RESENDE, O.; ARCANJO, R. V.; SIQUEIRA, V. C.; RODRIGUES, S. Modelagem matemática para a secagem de clones de café (Coffea canephora Pierre) em terreiro de concreto. Acta Scientiarum. Agronomy, Maringá, v.31, n.2, p.189196, 2009

26 SALEH, A.; BADRAN, I. Modeling and experimental studies on a domestic solar dryer. Renewable Energy, Oxford, v.34, n.10, p.2239-2245, 2009.

27 SANTOS, D. C.; QUEIROZ, A. J. M.; FIGUEIRÊDO, R. M. F.; OLIVEIRA, E. N. A. Drying of waste grains flour of annatto by using solar energy. African Journal of Agricultural Research, Lagos, v.7, n.47, p.6281-6288, 2012.

28 SANTOS, D. C.; QUEIROZ, A. J. M.; FIGUEIRÊDO, R. M. F.; OLIVEIRA, E. N. A. Cinética de secagem de farinha de grãos residuais de urucum. Revista Brasileira de Engenharia Agrícola e Ambiental, Campina Grande, v.17, n.2, p.223-231, 2013.

29 SANTOS, D. C.; QUEIROZ, A. J. M.; FIGUEIRÊDO, R. M. F.; OLIVEIRA, E. N. A. Secagem solar de grãos residuais e farinha de grãos residuais de urucum. Bioscience Journal, Uberlândia, v.30, n.2, p.436-446, 2014a.

30 SANTOS, D. C.; QUEIROZ, A. J. M.; FIGUEIRÊDO, R. M. F.; OLIVEIRA, E. N. A. Secagem de grãos residuais de urucum por exposição direta ao sol combinada com secagem em secador acumulador de calor. Semina: Ciências Agrárias, Londrina, v.35, n.1, p.277-290, 2014b.

31 SILVA, F. A. S.; AZEVEDO, C. A. V. Versão do programa computacional Assistat para o sistema operacional Windows. Revista Brasileira de Produtos Agroindustriais, Campina Grande, v.4, n.1, p.71-78, 2002.

32 SILVA, J. H. V.; SILVA, E. L.; JORDÃO FILHO, J.; RIBEIRO, M. L. G. Efeitos da inclusão do resíduo da semente de urucum (Bixa orellana $L$.) na dieta para frangos de corte: desempenho e características de carcaça. Revista Brasileira de Zootecnia, Viçosa, v.34, n.5, p.1606-1613, 2005. 
33 SLAMA, R. B.; COMBARNOUS, M. Study of orange peels dryings kinetics and development of a solar dryer by forced convection. Solar Energy, Freiburg, v.85, n.3, p.570-578, 2011.

34 STATSOFT, Inc. STATISTICA: data analysis software system. Version 7.0. Tulsa, 2004.

\section{ACKNOWLEDGMENT}

The authors would like to thank the Conselho Nacional de Desenvolvimento Científico e Tecnológico (CNPq) and the Coordenação de Aperfeiçoamento de Pessoal de Nível Superior (CAPES) for financial help and the Maratá food company for the donation of the annatto waste grains. 